\title{
DELeUZE E A PERVERSÃo ${ }^{1}$
}

Filipe Ferreira ${ }^{2}$

Resumo: Ainda que de modo introdutório, dizemos que existe um sujeito, o perverso, no interior da filosofia de Deleuze. Mais, que é tornando-se esse sujeito, fazendo do perverso um filósofo, que Deleuze dá início à sua filosofia, em Diferença e repetiçâa e na Lógica do sentido. Ou seja, que existindo um devirperverso do próprio Deleuze, esse devir condiciona uma abordagem à relaçáo do seu pensamento com o tema da perversão, e isto por ser justamente a criaçáo desse heterónimo, o perverso, que está na origem da sua filosofia.

Palavras-chave: Perversão. Personagem. Devir. Ilha. Estrutura.

\section{INTRODUÇÁO}

É comum se dizer que Deleuze perverte os autores de que trata. Ou que perverte campos inteiros, como o estruturalismo, a psicanálise, a crítica literária ou até a lógica. A verdade é que nada do que toca permanece intato. David Lapoujade (2015, p. 135), um dos poucos comentadores que aborda esse assunto, atribui a perversão em Deleuze a um procedimento ou método que "consiste em extrair uma espécie de duplo do original estudado". Pervertendo o original, o duplo vira-o do avesso, revertendo-o. A operaçáo consistiria em levar o original até uma espécie de limite ou fora, sendo o próprio duplo constituído ao longo do limite estabelecido. ${ }^{3}$ Perguntar-se-á o que é esse limite, o que é o fora de Kant ou de Espinosa, ou o que seria

\footnotetext{
${ }^{1}$ O presente trabalho foi realizado com apoio da Coordenação de Aperfeiçoamento de Pessoal de Nível Superior (CAPES).

${ }^{2}$ Pesquisador pós-doutoral no Programa de Estudos Pós-Graduados em Filosofia da Pontifícia Universidade Católica de São Paulo (PUC-SP), São Paulo, SP - Brasil. Doutor em Filosofia pela Universidade Nova de Lisboa. (1) https://orcid.org/0000-0001-7916-0397 E-mail: filiposophy@gmail.com

3 "A operação essencial da perversão deleuziana é a reversão. Acaso Deleuze não passou a vida pervertendo determinados autores, de Platão a Kant, até Bergson e Freud, extraindo a cada vez um duplo que o desloca, o vira do avesso ou o reverte?" [...] "Deleuze só faz causa comum com certos

http://doi.org/10.1590/0101-3173.2020.v43esp.06.p77
}

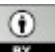

This is an open-access article distributed under the terms of the Creative Commons Attribution License. 
levar o estruturalismo, a psicanálise ou a lógica até um limite. Seja como for, a sensação que se tem de que Deleuze de fato cria duplos, perversóes dos seus originais, é indesmentível. É também indesmentível que essa sensação se agudiza, à medida em que entramos em Diferença e repetição e na Lógica do sentido.

Nessas obras, que marcam a gênese da filosofia de Deleuze, os duplos parecem ganhar outra vida, ser afirmados todos de uma vez, dessa vez do interior da sua filosofia. É como se, antes dessa génese, Deleuze produzisse retratos, de Nietzsche, Bergson etc., cada retrato criando um duplo do original tratado, sendo só realmente a partir de Diferença e repetiçáo que esses duplos encontram a sua verdadeira existência, a sua afirmação unívoca, onde, para além de reverterem os seus originais, eles agora se revertem uns aos outros, uns nos outros, dentro da filosofia de Deleuze. Uma perversão generalizada, portanto, que eleva a perversão pressuposta pela criação de duplos à sua enésima potência, e isto por agora se produzir duplos dos próprios duplos, reversốes de reversóes, com base nos quais se torna mais e mais irrelevante se se está a lidar com o original ou com os seus duplos, tornando-se, no limite, impossível distingui-los.

Não será de surpreender, por isso mesmo, que, no Prólogo de Diferença $e$ repetição, Deleuze diga que é "preciso expor um livro real da filosofia passada como se se tratasse de um livro imaginário e fingido". Ou que associe a reprodução em filosofia, a chamada "história da filosofia", à colagem na pintura. ${ }^{4} \mathrm{Ou}$ até que se vire para Borges, famoso pela "resenha de livros imaginários", quando ele considera o Dom Quixote reproduzido por Pierre Ménard, um escritor imaginário, mais real do que o original. ${ }^{5}$ É como se, a partir de Diferença e repetição, só existissem resenhas de livros imaginários, fingidos, só existissem duplos, colados uns nos outros, de tal maneira que os originais já nem regressam na forma de uma reminiscência, de uma memória que só se lembra que foram esquecidos. Perderam-se, tal a grossura das camadas criadas pelas duplicaçóes e reduplicaçóes de todos os duplos uns nos

autores porque, a cada vez, os reconduz a um fora, ao longo do limite estabelecido por seu duplo." (LAPOUJADE, 2015, p.135-36).

4 "Parece-nos que a história da filosofia deve desempenhar um papel bastante análogo ao da colagem numa pintura” (DELEUZE, 2000, p. 39).

5 "As resenhas de história da filosofia devem representar uma espécie de desaceleraçấo, de congelamento ou de imobilização do texto: não só do texto ao qual eles se relacionaram, mas também do texto no qual eles se inserem. Deste modo, elas têm uma existência dupla e comportam, como duplo ideal, a pura repetiçâo do texto antigo e do texto atual um no outro" (DELEUZE, 2000, p. 39). 
outros. Ou, pelo menos, é esse o alerta, tantas vezes ignorado, dirigido ao próprio leitor, com que começa Diferença e repetiçâo: se estiverem à espera dos originais, esqueçam.

Mas como se dá essa passagem, dos duplos extraídos de originais à sua afirmação, enquanto duplos, duplos de duplos, dessa vez no interior da filosofia de Deleuze? Uma resposta é ainda a de Lapoujade (2015, p. 137), que associa a reversão dos duplos uns nos outros a uma nova dimensão do método perverso. Assim, o método de extrair duplos, de reverter os originais, virando-os do avesso, desemboca, para ele, num "gigantesco método de dobragem", o qual se refere, justamente, a uma nova dimensão do método, já não simplesmente o de extrair duplos, mas de os fazer se duplicarem ou se dobrarem uns nos outros. ${ }^{6}$ Seja como for, é preciso perguntar se Lapoujade está correto em reduzir essa passagem a uma questáo metodológica, procedimental. É que, se repetirmos o que foi dito, que é justamente entre ambos os aspectos do método que se dá a gênese da filosofia de Deleuze, em Diferença e repetição, terá de se admitir que é já de dentro da sua filosofia, de Diferença e repetição, que os duplos são afirmados uns nos outros, que a perversão se generaliza. Que, por outras palavras, é o gigantesco método de dobragem que pressupóe o começo da filosofia de Deleuze e não o contrário.

Logo, e no que toca à relação da filosofia de Deleuze com a perversão, a questão mais imediata não será, a nosso ver, do desdobramento do método de extrair duplos no tal gigantesco método de dobragem, mas o que tem a perversão a ver com essa génese. E, em particular, de como ela se dá desde o período que antecede Diferença e repetição, quando Deleuze se entretinha com retratos perversos, enrabando os autores de que tratava, extraindo-lhes duplos, filhos monstruosos. ${ }^{7}$

\footnotetext{
${ }^{6}$ É já nos termos deste gigantesco método de dobragem que "Nietzsche repete Leibniz, é como um duplo de Leibniz, mas Leibniz já repete Nietzsche, assim como os estoicos repetem Leibniz e Nietzsche a seu modo, [sendo que, agora noutra série,] Nietzsche por sua vez repete Espinosa, assim como Bergson se repete em Espinosa, e vice-versa, cada um sendo um duplo do outro", etc. (LAPOUJADE, 2015, p.137).

7 É o próprio que o afirma na famosa "Carta a um crítico severo": "[A] principal maneira de me safar nessa época [o período das "monografias", da extração de duplos, antes de Diferença e repetição] foi concebendo a história da filosofia como uma espécie de enrabada, ou no que dá no mesmo, de imaculada concepção. Eu imaginava-me a chegar pelas costas de um autor e a fazer-lhe um filho, que seria seu e, no entanto, seria monstruoso. Que fosse seu era muito importante porque o autor precisava efetivamente de ter dito tudo aquilo que lhe fazia dizer. Mas que o filho fosse monstruoso também representava uma necessidade, porque era preciso fazer passar por toda a espécie de descentramentos, deslizes, quebras, emissōes secretas que me deram muito prazer”. (DELEUZE, 1992, p.14).
} 
É por assumirmos que o que há de realmente perverso na filosofia de Deleuze não se refere tanto aos duplos, mas sim à génese, ela mesma, da sua filosofia; é por sentirmos, por outras palavras, que há uma perversão na sua filosofia que extravasa o próprio método, seja ele o de extrair duplos ou de dobrá-los uns nos outros, que começaremos com algo que Lapoujade (surpreendentemente) rejeita: o fato de Deleuze ser um perverso. ${ }^{8}$ Ora, a nosso ver, ele não é outra coisa, pelo menos até $O$ anti-Édipo, até Guattari. ${ }^{9}$ Entre o período dos diferentes retratos e Diferença e repetição, onde se dá a génese da sua filosofia, Deleuze não só inventa o perverso enquanto sujeito, porém, se torna ele mesmo esse sujeito, o perverso, ao fazer dele um filósofo.

\section{Ou seja, o que há de realmente perverso na filosofia de Deleuze é o} fato de ser um perverso que pensa Diferença e repetição e também a Lógica do sentido. De ser ele que dobra todos os duplos uns nos outros, generalizando a perversão, e isto por ser justamente ele, o perverso, o filósofo dessas obras. Dos retratos perversos à génese da sua filosofia, há o devir-perverso de Deleuze, a

8 "Não se deve concluir que Deleuze é um perverso, mas sim que instaura um procedimento ou método perverso". Lapoujade, Deleuze, os movimentos aberrantes, p.135. Mas que fique claro: é estritamente enquanto filósofo que afirmamos Deleuze como perverso. Aliás, não poderia ser de outra maneira: é no pensamento, na filosofia, que o personagem existe enquanto "conceitual". O personagem conceitual se refere exclusivamente ao devir do pensador, à maneira em que o pensador faz de um personagem um filósofo, um pensador. Ou seja, não nos referimos ao personagem no que é historicamente, socialmente, mitologicamente, literária ou clinicamente. Muito menos é o filósofo enquanto um "eu penso" que está aqui em jogo. Quando falamos de um "sujeito" filosófico, não supomos de todo este "eu penso". Muito pelo contrário: enquanto personagem, o sujeito pensante é sempre uma "terceira pessoa", e isto, simplesmente, pelo personagem ser outro ao filósofo (ao "eu penso") tanto quanto ser filósofo é outro ao personagem. É criando a filosofia do perverso que o filósofo é perverso, se torna perverso, tanto quanto é neste devir que o perverso se torna filósofo, se afirma como um filósofo. O devir do filósofo é, portanto, um duplo devir outro: do filósofo no outro de si mesmo (em personagem), mas também do personagem, que tornando-se filósofo, torna-se outro do que é historicamente, socialmente, mitologicamente, etc. Uma heteronomia filosófica onde quem pensa é sempre uma terceira pessoa, onde, como dizem Deleuze-Guattari, "o filósofo é somente o invólucro do seu personagem conceitual principal e de todos os outros, que são seus intercessores, os verdadeiros sujeitos da sua filosofia". (DELEUZE, 1997, p. 86 - o grifo em "sujeitos" é meu). Perguntando-se, na página seguinte, "Quem é eu?", ou seja, que "eu” é esse que o personagem conceitual afirma, eles respondem repetindo o que já vimos, que "é sempre uma terceira pessoa".

9 $O$ anti-Édipo, de Deleuze-Guattari, é o primeiro volume de Capitalismo e esquizofrenia (o segundo é Mil platôs, 1980), e aparece em 1972, imediatamente após Diferença e repetiçâa (1968) e a Lógica do sentido (1969). Deleuze e Guattari conhecem-se em 1969. Ainda que não o abordemos aqui, pelo fato de a nossa atenção estar virada para a relação da filosofia de Deleuze com a perversão, e como essa relaçấo pode ser pensada nos termos da criação, na sua filosofia, do perverso enquanto personagem conceitual, é de se sublinhar que, com Guattari, surge um novo personagem conceitual, personagem este, diríamos, cuja criação é a razão essencial do encontro Deleuze-Guattari: falamos, evidentemente, do esquizo. Isto é, o perverso, a nosso ver, é dominante na filosofia de Deleuze, mas só até esse encontro e do projeto geral de Capitalismo e esquizofrenia. 
maneira em que Deleuze se torna perverso, fazendo dele um filósofo, quem de direito pensa Diferença e repetição e a Lógica do sentido, quem em nome do qual essas obras são de fato pensadas. O que é a filosofia, enquanto pensada por um perverso? A resposta, nem mais, é Diferença e repetição, a Lógica do sentido, o conjunto de ambas as obras. Todavia, para lá chegarmos, é preciso primeiro abordar como surge esse sujeito, o perverso, no pensamento de Deleuze. É só depois que, tornando-se esse sujeito, ele o tornará filósofo, o seu heterónimo, o pensador na génese da sua filosofia.

\section{O PERVERSO E O DEVIR-PERVERSO}

É preciso reconhecer, no entanto, que, ao contrário de $O$ anti-Édipo, onde o esquizo aparece em tantas das suas páginas, não encontramos uma referência sequer ao perverso em Diferença e repetição. São também poucas as que encontramos na Lógica do sentido, as principais surgindo marginalmente num dos seus apêndices, o que Deleuze (2006, p. 311-30) dedica a Vendredi ou les limbes du Pacifique, de Michel Tournier. ${ }^{10}$ Ainda assim, a Lógica do sentido inclui importantes referências à perversão (não muitas, é verdade), em função das quais é possível determinar uma relação concreta desse tema com as suas principais linhas. Antes de mais, na relação da perversão com a ontologia proposta, a que Deleuze (2006, p. 212) atribui aos estoicos.

Afirmando que "a 'perversidade' é o atravessar das superfícies", Deleuze associa a perversão à concepção de uma superfície metafísica, ou seja, à principal categoria ontológica proposta na Lógica do sentido. Mas ele também associa a perversão ao próprio filósofo, ou, pelo menos, a uma nova "imagem do

${ }^{10}$ A única outra referência ao perverso que encontramos na Lógica do sentido aparece com o confronto entre as linguagens de Antonin Artaud e Lewis Carroll (na 13a série, 2006, p. 95): "Nem por isso é menos execrável e deplorável misturar tudo [a superfície e o sem-fundo, Carroll e Artaud, a linguagem da menina e a do esquizofrênico], seja a conquista da superfície na criança, seja a falência da superfície no esquizofrênico, seja o controle das superfícies naquele que chamamos - por exemplo - perverso". Associando a menina, a Alice, a uma linguagem de superfície, que seria a linguagem de Carroll e não a do esquizofrênico, de Artaud, Deleuze associa a conquista da superfície por parte da criança (e, por consequência, a linguagem de Carroll) ao perverso. $\mathrm{O}$ perverso, com a sua linguagem, seria um exemplo do "controle das superfícies", um pouco como se se assumisse a sua capacidade de operar sobre esta superfície, de se movimentar sobre ela, de construíla, organizá-la, de distribuir sobre ela diferentes realidades (virtualidades). 
filósofo". ${ }^{11}$ Assumindo existir "um novo tipo de filósofo", precisamente o das superfícies, esse filósofo, com o qual Deleuze se identifica, não só entende o seu fazer filosofia como "uma estranha arte das superfícies", entretanto afirma, explicitamente, que a essa arte, com o seu "sistema de provocaçóes", convém a "palavra perversão". ${ }^{12} \mathrm{Em}$ todo caso, essa arte, a das superfícies, não se limita à filosofia, sendo também atribuída, por Deleuze, às próprias artes e, em particular, ao artista. Pelo menos na Lógica do sentido, esse artista é Lewis Carroll. Encenando exemplarmente os paradoxos do sentido e, em particular, o seu paradoxo essencial, que é o de o sentido pressupor uma relação intrínseca com o não-sentido, Carroll não só cria uma língua estrangeira, no interior da linguagem, mas revela, com a língua que cria, uma nova organização da própria linguagem em geral. É como se existisse uma organizaçáo da linguagem enquanto "reduzida" ao sentido, enquanto, por outras palavras, organizada ao longo dos paradoxos constitutivos do sentido. ${ }^{13}$

Uma das apostas centrais da Lógica do sentido é a que concebe essa linguagem como estando na origem da proposição nas suas relações ordinárias (de designação, manifestação e significação), sendo ela mesma pressuposta por uma “ordem primária terrível” (DELEUZE, 2017, p. 85). Essa ordem é definida pela linguagem do esquizofrênico, por uma ordem da linguagem onde o não-sentido muda de figura, engolindo o sentido, que deixa de ser expresso a partir do náo-sentido. $\mathrm{Na}$ Lógica do sentido, tudo se divide, portanto, entre uma ordem primária (esquizofrênica) da linguagem e a proposição, nas suas

${ }^{11}$ Cf., a $18^{a}$ série "Das três imagens de filósofos" (p.131-36). A Lógica do sentido praticamente começa (na $2^{a}$ série, "Dos efeitos de superfície", p. 5-12) com a atribuição dessa superfície metafísica ao gênio dos estoicos: "O gênio de uma filosofia mede-se, em primeiro lugar, pelas novas distribuiçóes que impóe aos seres e aos conceitos. Os estoicos estão em vias de traçar, de fazer passar uma fronteira [uma superfície] onde nenhuma havia alguma vez sido avistada" (p. 7). A razão pela qual essa superfície é "metafísica" precisa de uma análise mais cuidada (é num sentido muito especial que é metafísica...), que incide também sobre o sentido do "metafísico" na obra de Deleuze.

12 "Talvez pela palavra perversão, que convém pelo menos ao sistema de provocaçóes deste novo tipo de filósofos, se é verdade que a perversão implica uma estranha arte das superfícies" (DELEUZE, 2006, p.136).

${ }^{13}$ Mas que mais parece uma expansão da linguagem, expansão que é até compreensível pelo sentido constituir, em relação às dimensôes ordinárias da proposição, as de designação, manifestação e significação, uma "quarta dimensão". Seja como for, o termo "reduçáa" corresponde ao ponto de vista genético, a partir do qual essa quarta dimensão é considerada como primeira, ou seja, como originária em relação às outras dimensóes da proposição. Abordada enquanto tal, na sua "irredutibilidade" mas também no seu "poder de génese", essa dimensão, a do sentido, envolve não só uma organização da linguagem que lhe é própria, mas é ela mesma a condiçâo genética da proposição. "O sentido é a quarta dimensão da proposição ... [Quando] a proposição "aparece por si mesma e na sua irredutibilidade, mas também no seu poder de génese, [ela anima] então um modelo interior a priori da proposição" (DELEUZE, 2006, p. 20-21). 
relaçôes ordinárias. É entre esses polos que se encontra a língua de Carroll, a organização da linguagem enquanto imanente ao sentido. É entre esses polos, por outras palavras, que se joga o destino de uma 'lógica do sentido'. Se, ontologicamente, a superfície metafísica é uma dupla perversão, tanto do alto das Ideias platônicas como do sem-fundo dos simulacros pré-socráticos, linguisticamente, a língua estrangeira criada por Carroll é, também ela, essa dupla perversão, dessa vez tanto da proposição nas suas relaçôes ordinárias como da linguagem do esquizofrênico.

Assim como os estoicos o fizeram, Deleuze instaura uma superfície metafísica, ainda que o faça nos termos da língua estrangeira criada por Lewis Carroll (ou seja, de uma nova teoria da linguagem, que é a lógica do sentido). ${ }^{14}$ Em ambos os casos, a operação perversa é a mesma: ela consiste em criar um movimento que perverte duplamente, no mesmo movimento, tanto o alto como o profundo, instaurando uma superfície metafísica, ela mesma uma dupla perversão do metafísico e do transcendental. E, se é preciso uma nova imagem do filósofo, é porque a própria imagem do que significa pensar se perdeu. Ela se perdeu no abismo esquizofrênico, donde o pensamento começa, sem imagem, para construir uma superfície metafísica e, a partir dela, fazer nascer o mundo que circula na proposição, o mundo, enfim, cujo limite, do ponto de vista da significação, é o limite do verdadeiro e do falso, do absurdo enquanto limite de ambos. É agora o filósofo, Deleuze, que opera o controle das superfícies, que extrai uma organização geral da linguagem da língua criada por Carroll, que pensa essa organização nos termos de uma superfície metafísica, que até extrai um humor perverso dos paradoxos do sentido, da arte de fazer nascer o próprio mundo da linguagem que se organiza no interior da colisão entre o sentido e o não-sentido. ${ }^{15}$

${ }^{14}$ Embora os próprios estoicos também o tenham feito, nos termos de uma teoria da linguagem. Deleuze (2006, p. 9) reconhece-o explicitamente, já na Lógica do sentido (a sua insistência, por exemplo, na famosa frase de Crisipo: "Se dizes alguma coisa, esta coisa passa pela tua boca; ora, tu dizes uma carroça, logo uma carroça passa pela tua boca”) mas também com Guattari (2015, p. 27-9), ao voltar a insistir que os estoicos foram os primeiros a reconhecer a independência dos incorporais, dos atos incorpóreos, ou seja, dos acontecimentos (ou atos) internos à linguagem, atribuíveis às coisas. Desse ponto de vista, o uso de Lewis Carroll por parte de Deleuze, na Lógica do sentido, funcionaria como uma espécie de atualização da teoria da linguagem dos estoicos, ela mesma assente num duplo (perverso) da filosofia dos estoicos (sendo, portanto, no duplo de Carroll que se dobra o duplo dos estoicos e vice-versa).

15 "O humor é a arte das superfícies [que suspende] toda significação, designação e manifestação, abolindo toda profundidade e altura” (idem, p.143). 
Tudo isso já seria suficiente para questionar Lapoujade, o qual limita o tema da perversão em Deleuze ao método de extrair duplos e de os revirar uns nos outros. Afinal, se a Lógica do sentido nos permite supor que existe, na filosofia de Deleuze, um movimento perverso, o que perverte o alto e o profundo, instaurando uma nova dimensão ontológica, a de uma superfície metafísica, parece claro que seria nos termos desse movimento que esses duplos teriam de ser pensados e não o inverso. É como se os próprios duplos encontrassem um movimento táo perverso quanto eles, no interior do qual se reviram ou duplicam uns nos outros, generalizando assim a perversáo em que o próprio método se desdobra.

Seja como for, não é de todo evidente o que esse movimento terá a ver com o perverso enquanto sujeito ou com o devir-perverso de Deleuze. Existe, claro, a possibilidade de simplesmente atribuir esse movimento a um perverso, de dizer que, se se trata de um movimento perverso, é por existir um perverso que o pensa enquanto tal, sendo esse perverso o próprio Deleuze. Essa possibilidade seria reforçada com a nova imagem do filósofo proposta por Deleuze, na Lógica do sentido. Há até uma linguagem perversa atribuível ao perverso, a que é organizada ao longo da própria superfície, a partir da língua estrangeira criada por Carroll. Ou seja, existe a linguagem do perverso. Existe a concepção do próprio perverso enquanto filósofo. Existe também uma operação ontológica perversa, uma espécie de ontologia perversa que consiste na tal dupla perversão do alto e do profundo. Esses elementos já não chegariam para se supor o perverso como um personagem conceitual, no interior da obra de Deleuze?

A verdade é que estamos ainda longe desse personagem. Podemos falar de uma ontologia perversa, de uma linguagem perversa, até de um filósofo perverso: nada disso é o que temos em mente, ao assumirmos que existe um perverso e um devir-perverso, no interior da obra de Deleuze. É preciso que fique claro: para nós, é o devir-perverso de Deleuze que condiciona a génese da sua filosofia, em Diferença e repetição, e não o contrário. É nos termos desse devir que nascem obras tão centrais ao conjunto da sua obra, como Diferença e repetição e a Lógica do sentido. Quer dizer, é o devir-perverso de Deleuze que condiciona toda a maquinaria conceitual criada nessas obras, inclusive a perversidade que se associa à concepção de uma superfície metafísica, a uma linguagem que é imanente a essa superfície ou à imagem do filósofo como construtor de superfícies. Todavia, é preciso reconhecer que, se algo como um 
sujeito, o perverso, não é de todo evidente na obra de Deleuze, muito menos será o seu devir-perverso, que dizemos estar na origem da sua própria filosofia.

Teremos, portanto, de construir esse devir, o do próprio Deleuze, no interior do seu pensamento, da sua filosofia. Para tal, teremos de começar com o perverso, e isto por ser justamente este o sujeito que Deleuze se torna, o qual, tornando-se nele, faz dele um pensador, um filósofo. Mas por onde começar com o perverso, com a sua construção enquanto sujeito? Onde começaremos se, no que se refere à obra de Deleuze, rejeitamos limitar a análise da perversão, seja a uma questão de método, como faz Lapoujade, seja à perversão que se associa à superfície metafísica enquanto categoria ontológica central da Lógica do sentido? Se, para nós, tanto quanto a maquinaria conceitual de Diferença e repetição e da Lógica do sentido, é também a própria perversão que terá, na sua obra, de ser pensada a partir do seu devir-perverso, da maneira em que Deleuze faz desse sujeito, o perverso, um filósofo, um pensador?

\section{ILHA DESERTA, ESTRUTURA PERVERSA}

O que procura Deleuze na perversão? Para além do que diz sobre enrabar autores, ou da maneira em que relaciona a superfície metafísica à perversão, existem, claro, as análises de Sade, Masoch e Klossowski, o interesse, em especial, de Deleuze pelo masoquismo. ${ }^{16}$ Todavia, não é nesses estudos, onde talvez se esperaria que o fizesse, que Deleuze melhor define o que lhe interessa na perversão. É como se, existindo um perverso na sua obra, esse sujeito não pudesse se limitar ao sádico, ao masoquista ou ao pornólogo, muito menos a

\footnotetext{
${ }^{16}$ Em Critica e clínica, por exemplo, Deleuze (1997, p. 64-66) dedica um capítulo exclusivamente a Masoch. Apostando em desmanchar a unidade dialética na origem de um suposto sadomasoquismo, Sacher-Masoch (DELEUZE, 2009) é exemplar quanto ao esclarecimento do quadro sintomatológico inerente à linguagem de Masoch, ou seja, das originalidades literárias que estariam na origem do próprio quadro clínico masoquista. Mas, antes mesmo de Sacher-Masoch e da entrevista que Deleuze (2005) dá, em 1967, a propósito da sua publicação (onde a ênfase, mais uma vez, incide sobre Masoch e o masoquismo), existe um texto de 1961, "De Sacher-Masoch ao masoquismo" (2017), onde Deleuze já introduz os principais eixos da sua leitura de Masoch (a questão do contrato, por exemplo), embora a maneira em que relaciona o masoquismo a uma teoria do inconsciente seja inteiramente inicial. Curiosamente, em 1961, Deleuze (2017, p. 104) aposta em Jung, associando os dados revelados pelo masoquismo a uma dimensão mais profunda do inconsciente, que define (bergsoniamente...) como os "dados irredutíveis do inconsciente". Assim, é nos termos da teoria clínica de Jung que esses dados (especialmente referentes aos temas da mãe, do incesto, da morte e do nascimento) são tratados simbolicamente, mitologicamente. Talvez seja por essa razão que Lapoujade tenha optado por não incluir esse texto em $A$ ilha deserta e outros textos, onde recolhe textos e entrevistas de Deleuze de 1953 a 1974. Seja como for, o especial interesse de Deleuze por Masoch e pelo masoquismo é evidente, atravessando o conjunto da sua obra desde de, pelo menos, 1961.
} 
um perverso induzido em função das escassas referências à perversão, na Lógica do sentido. É algo de outra ordem que Deleuze procura na perversão. E esse algo é o seu aspecto estrutural, a estrutura que os próprios comportamentos perversos preenchem e, enquanto tal, pressupóem como sua condição. Já no texto que dedica a Klossowski, Deleuze (2006, p. 289) assevera:

De certa maneira, a nossa época descobre a perversão. Ela não tem necessidade de descrever comportamentos, de compor narrativas abomináveis. Sade precisava disso, mas há um legado de Sade. Procuramos antes a 'estrutura', isto é, a forma que pode ser preenchida por estas descriçôes e narrativas (uma vez que as torna possíveis), mas que não tem necessidade de o ser para ser dita perversa.

Ainda assim, não nos parece que, para Deleuze, seja Klossowski a definir essa estrutura. É verdade que Klossowski concebe a perversão estruturalmente. ${ }^{17}$ Mas, se não é esta a estrutura que Deleuze tem em mente, é por se supor que os "corpos-linguagem" definidos por Klossowski se encontram, eles mesmos, envolvidos noutra estrutura, mais ampla, que os condicionaria, tornando-os por sua vez possíveis. Nesse sentido, se o sádico e o masoquista supóem a estrutura ou corpos-linguagem que o pornólogo concebe, existiria ainda outra estrutura, que o próprio pornólogo pressuporia tanto quanto o sádico e o masoquista. ${ }^{18}$ E que estrutura é esta? Por mais estranho que pareça, quando Deleuze pensa a estrutura pressuposta pela tríade de perversos, pelo sádico, o masoquista e o pornólogo, ele o faz segundo um personagem que não apresenta nenhum comportamento perverso, nem parece acrescentar seja o que for ao entendimento geral da perversão. Mesmo assim, é nos seus termos que pensará a estrutura perversa. E quem é ele? Ora, trata-se de Robinson Crusoé, não o Robinson de Daniel Defoe, certamente, mas o que aparece em Vendredi ou les limbes du Pacifique, de Michel Tournier. ${ }^{19}$ Contra todas as expectativas, é a aventura de Robinson, tal como descrita por Tournier e analisada por Deleuze, que confirma, na sua filosofia, o seu interesse por uma concepção estrutural

\footnotetext{
${ }^{17} \mathrm{E}$ isto por definir os “corpos-linguagem”, isto é, a espécie de paralelismo entre o corpo e a linguagem (ou disjunçáo inclusiva entre ambos) pressuposta por uma pornologia superior e, enquanto tal, pelas linguagens de Sade e de Masoch como casos evidentes (ainda que de maneiras diferentes) dessa pornologia (DELEUZE, 2006, p. 289-309).

${ }^{18}$ Tomamos a liberdade de associar o "pornólogo" ou a "pornologia" a Klossowski, e isto precisamente pelo que já foi destacado: que, a nosso ver, é ele que define as condiçôes reais para as diferentes linguagens que constituem uma pornologia superior.

19 "É preciso imaginar Robinson perverso; a única robinsonada é a própria perversão" (DELEUZE, 2006, p. 330).
} 
da perversão e, em particular, a relação do tema da ilha deserta com essa concepção. Em Deleuze, a ilha deserta é perversa, estruturalmente perversa. É a ilha deserta que define estruturalmente a perversão.

Porém, o que é, realmente, uma ilha deserta? $\mathrm{Na}$ sua análise do Robinson de Tournier, Deleuze diz que se trata de um mundo sem outrem. É importante realçar, no entanto, que esta não é a única concepção da ilha deserta presente na sua obra. Num texto inicial dos anos 50, Deleuze também pensa a ilha deserta estruturalmente, dessa vez, do ponto de vista genético, como uma segunda origem. Deleuze afirma (2005, p. 7) que a ilha "não é o começo mas o recomeço", que ela é o "mínimo necessário para esse recomeço, o material sobrevivente da primeira origem, o núcleo ou o ovo irradiante que deve bastar para reproduzir tudo". Se perguntarmos o que muda de uma concepção a outra, não custa perceber que concerne ao ponto de vista do náufrago. $\mathrm{O}$ problema que se coloca com Robinson é o da sua relação com a ilha, de como ele a habitará. Não se trata de todo do mesmo problema do texto inicial dos anos 50 .

Ainda que aluda ao problema do náufrago, o de habitar a ilha, e até o faça segundo termos que Tournier desenvolverá, ${ }^{20}$ o que interessa a Deleuze, no texto da sua juventude, não é tanto o que é a ilha deserta para o náufrago, mas o que ela é em si mesma. É em si mesma que a ilha deserta aparece como a repetição da origem, eternamente uma segunda origem. É também enquanto repetição da origem que ela é a origem de si mesma. A ilha deserta nasce, ela mesma, repetindo a origem. Ela é a sua própria causa, tanto quanto é, eternamente, uma origem dupla, bastarda, falsa. Todavia, para o náufrago, cujo problema é o de povoar a ilha, a ilha jamais será, para ele, o que ela é em si mesma. E isto por uma razão simples: existindo um náufrago na ilha, a ilha será sempre relativa ao seu ponto de vista. Compreende-se, portanto, que não se trata de todo de perguntar como ambas as concepçóes da ilha deserta combinam para afirmar a ilha como estruturalmente perversa. Se existem duas concepçóes estruturais da ilha, elas deverão se manter enquanto tal, separadas, e isto por corresponderem a dois pontos de vista irredutíveis. Em todo caso, o que aparentemente se torna cada vez mais obscuro é a relação da ilha deserta

\footnotetext{
${ }^{20}$ Quando assevera: "Para que uma ilha deserta deixe de ser deserta, não basta, com efeito, que ela seja habitada. Se é verdade que o movimento do homem em direção à ilha retoma o movimento da ilha antes dos homens, ela pode ser ocupada por homens em geral, mas é ainda deserta, desde que eles estejam suficientemente, isto é, absolutamente separados, desde que eles sejam suficientemente, isto é, absolutamente criadores. Sem dúvida, de fato, isso nunca é assim, se bem que o náufrago se aproxime dessa condiçăo" (DELEUZE, 2005, p. 5).
} 
com a perversão e, em particular, com o perverso enquanto sujeito. Como poderão existir, não uma, mas duas estruturas, e ainda por cima de algo tão inocente como uma ilha deserta, na origem dos comportamentos perversos, das narrativas abomináveis, das diferentes linguagens da perversão? Afinal, quem é o perverso? Como nascerá esse sujeito, no interior da obra de Deleuze?

Em Deleuze, o perverso é quem repete a ilha deserta para si próprio. $\mathrm{O}$ que define o perverso enquanto sujeito é precisamente essa repetição. Mas ele repete a ilha duplamente. São ambas as concepçóes estruturais da ilha deserta que o perverso repete para si mesmo. Ele repete a ilha como segunda origem, tanto quanto a repete como um mundo sem outrem. E é também essa dupla repetição que diferencia a tríade de perversos. Ou seja, é repetindo para si mesmo ambas as concepçóes estruturais da ilha deserta que nasce o perverso. Contudo, é também repetindo essas estruturas que o perverso se diferencia, se singulariza, no sádico, no masoquista e no pornólogo. É um pouco como se, nelas mesmas, cada concepçáo estrutural da ilha deserta valesse, como frisamos, por si própria, sendo só realmente relacionadas, na sua irredutibilidade, do ponto de vista do perverso, de um terceiro, que repete ambas as estruturas para si mesmo. Repetindo para si mesmo a repetição eterna da origem, um mundo sem outrem, ou a maneira em que o Robinson de Tournier povoa esse mundo, o perverso é essa repetição. E não nos parece muito importante que, pelo menos explicitamente, Deleuze só tenha associado a perversão estruturalmente a um mundo sem outrem. ${ }^{21}$ Que, por outras palavras, não tenha avançado com a concepção estrutural da perversão que propomos, assente na dupla repetiçáo da ilha deserta, o que permite, por sua vez, uma análise estrutural da sua leitura do sadismo, do masoquismo e da pornologia.

Jamais saímos de Deleuze, do interior da sua obra. Ambas as concepções da ilha deserta são suas. São também suas as análises do sadismo, do masoquismo, da pornologia, a sua insistência nos poderes da repetição e até (com Guattari) a ideia de pensar a criaçáo filosófica, a partir de personagens conceituais. $\mathrm{O}$ único aspecto que esclarecemos, e isto por nos parecer implícito, é o ponto de vista de um sujeito em particular, do perverso. Esse ponto de vista é definido pela

\footnotetext{
${ }^{21}$ Em particular, no último parágrafo de "Michel Tournier e o mundo sem outrem" (2006, p. 329): "É porque a estrutura outrem falta, substituída por uma outra estrutura, onde os 'outros' reais já não podem desempenhar o papel de termos que efetuam a primeira estrutura desaparecida, mas somente na segunda, o papel de corpos vítimas (no sentido muito particular que o perverso atribui aos corpos) ou o papel de cúmplices-duplos, cúmplices-elementos (aí ainda no sentido muito particular do perverso), que o mundo do perverso é um mundo sem outrem" "O altruicídio não é cometido pelo comportamento perverso, mas sim suposto na estrutura perversa”.
} 
repetição da ilha deserta em ambas as suas estruturas constitutivas. O perverso é essa repetição, esse ponto de vista. $\mathrm{O}$ sádico, o masoquista e o pornólogo repetem o que o perverso repete, a ilha deserta, mas cada um à sua maneira. A origem estrutural do sadismo, do masoquismo e da pornologia é agora essa diferenciação interna, esse desdobramento ou multiplicação do próprio perverso em diferentes "casos", diferentes naturezas de si mesmo.

\section{O DEVIR-PERVERSO De DeLEUZE}

O que se apresenta é um esboço geral. Se o estudo da perversão na filosofia de Deleuze não se reduz a um método perverso ou à relação do próprio tema com certos aspectos da sua filosofia, é porque, para além da perversáo, existe o perverso, o sujeito, mas também o devir-perverso de Deleuze. O devirperverso de Deleuze é a génese da sua filosofia. É nos termos dessa génese que nasce a maquinaria conceitual de Diferença e repetição e da Lógica do sentido. Entretanto, essa génese, esse devir, não coincide nem com a maquinaria conceitual nem com o perverso enquanto sujeito. Ele está entre esse sujeito e os seus conceitos. É do sujeito que se cria o devir-perverso de Deleuze, a génese da sua filosofia, tanto quanto é desse devir, dessa génese, que nasce a maquinaria conceitual deleuziana, os conceitos da diferença, da repetição, do acontecimento, da superfície, da univocidade, do virtual, da dobra etc. O que se apresenta, em suma, é uma teoria geral da perversão assente tanto na repetição da qual nasce o perverso como na diferenciação dessa repetição, donde surgem o sádico, o masoquista e o pornólogo. Há o sujeito, a diferenciação interna do ponto de vista do perverso, nos casos do sádico, do masoquista, do pornólogo. Há também a filosofia do perverso, que dura até $O$ anti-Édipo, até Guattari e o esquizo. Entre esse sujeito e a sua filosofia, há o devir-filósofo do sujeito, do perverso, há o devir onde o próprio filósofo, Deleuze, se torna esse sujeito, o perverso. O devir-perverso de Deleuze é este duplo devir, o devir-filósofo do perverso, o devir-perverso do filósofo. Ele é a construção do pensamento a partir do qual o perverso criará a génese da filosofia de Deleuze.

Perguntar-se-á o que é esse pensamento, como poderá o pensamento do perverso estar na origem dos conceitos criados em Diferença e repetiçâo e da Lógica do sentido, ou, até, se será realmente viável falar do pensamento de Deleuze sem supor os seus conceitos. Por agora, sublinhemos o que condiciona uma investigação dessa natureza. Trata-se da aposta que fazemos nos personagens conceituais, em perguntar o que seria abordar a filosofia de Deleuze em funçáo 
dos seus heterônimos, a partir de uma espécie de heteronomia filosófica interna à sua obra. Por um lado, basta folhar $O$ anti-Édipo, onde surge um novo personagem conceitual, o esquizo, para se saber que não é com o perverso que essa história termina. Por outro, se é realmente com o perverso que ela começa, torna-se crucial esclarecer em que sentido ela realmente o faz, tal é a natureza implícita ou escondida da sua existência, no interior da obra de Deleuze, ao contrário do esquizo, claramente o personagem conceitual principal do projeto geral de Capitalismo e esquizofrenia. Qual a relaçáo da filosofia de Deleuze com a perversão? É nos termos da construção do perverso enquanto personagem conceitual, filósofo, que, para nós, a relação da filosofia de Deleuze com a perversão terá de ser entendida. Mas, para tal, torna-se necessário estabelecer o ponto de vista desse sujeito, do perverso, no interior da sua filosofia.

A definição desse ponto de vista depende da insistência, por parte de Deleuze, numa concepção estrutural da perversão. É o próprio Deleuze que, na sua análise do Robinson de Tournier, relaciona a perversão estruturalmente ao tema da ilha deserta. $\mathrm{O}$ que acrescentamos foi a inclusão nessa relação de mais uma concepção da ilha deserta, ela mesma inicial na filosofia de Deleuze. Definimos dois pontos de vista, duas maneiras de conceber a ilha, em si enquanto segunda origem, porém, também do ponto de vista do náufrago, de Robinson, enquanto mundo sem outrem. O perverso é quem repete ambas essas estruturas para si próprio. Ele repete a ilha deserta para si mesmo, no que ela é em si. Ele também a repete para si mesmo, no que ela é para o náufrago, para Robinson. Ele repete-a tanto como segunda origem como mundo sem outrem. E, se o seu ponto de vista é a origem estrutural da perversão, é pela circunstância de as perversóes do sádico, do masoquista e do pornólogo serem também, estruturalmente, repetiçóes da ilha deserta, diferenciaçóes internas da dupla repetição da ilha deserta.

Repetiçôes e mais repetições, é abordando cada uma delas que, do perverso à tríade de perversos, se constrói o pensamento do perverso, o pensamento que, não coincidindo com os conceitos de Diferença e repetição e da Lógica do sentido, está na origem deles, tanto quanto está na origem dessas obras e da própria filosofia de Deleuze. A criação dessa génese é a aventura do devir-perverso de Deleuze. É a aventura filosófica onde o personagem conceitual se afirma, tal como o definimos: como o encontro do filósofo com um sujeito interno ao seu pensamento, o sujeito que o filósofo fará um personagem conceitual, encontrando nele o devir na origem dos conceitos que criará enquanto heterónimo, outro de si mesmo. Enquanto Deleuze, o perverso... 
FERREIRA, F. Deleuze's Becoming-Pervert. Trans/form/ação, Marília, v. 43, p. 77-92, 2020. Edição Especial.

\begin{abstract}
Even if only schematically, we say there is a subject, the pervert, in Deleuze's philosophy. More, that it is by becoming this subject, making the pervert a philosopher, that Deleuze brings about the beginning of his own philosophy in Difference and Repetition and The Logic of Sense. In other words, that there is such a thing as Deleuze's very own becoming-pervert, being this becoming which conditions an understanding of the relation of his thinking with the question of perversion precisely because it is this heteronym, the pervert, who stands at the origin of his philosophy.
\end{abstract}

Keywords: Perversion. Personae. Becoming. Island. Structure.

\title{
REFERÊNCIAS
}

DELEUZE, Gilles. As causas e razóes da ilha deserta. Trad. Luiz Orlandi. In

DELEUZE, Gilles. A ilha deserta e outros textos. São Paulo: Iluminuras, 2005a, p. 5-7.

DELEUZE, Gilles. De Sacher-Masoch ao masoquismo. Trad. André Parente. Trágica, Rio de Janeiro, v. 10, p. 94-105, 2017.

DELEUZE, Gilles. Carta a um crítico severo. Trad. Peter Pál Pelbart. In DELEUZE, Gilles. Conversaçôes. São Paulo: Editora 34, 1992, p. 11-22.

DELEUZE, Gilles. Crítica e clínica. Trad. Peter Pál Pelbart. São Paulo: Editora 34, 1997.

DELEUZE, Gilles. Diferença e repetiçáo. Trad. Roberto Machado e Luiz Orlandi. Lisboa: Relógio D’Água, 2000.

DELEUZE, Gilles. Lógica do sentido. Trad. Luiz Salinas Fortes. São Paulo: Perspectiva, 2006

DELEUZE, Gilles. Sacher-Masoch: o frio e o cruel. Trad. Jorge de Bastos. Rio de Janeiro: Zahar, 2009.

DELEUZE, Gilles; GUATTARI, Félix. Mil platôs (vol.2), Trad. Ana Lúcias de Oliveira e Lúcia Cláudia Leão. São Paulo: Editora 34, 2015.

LAPOUJADE, David. Deleuze, os movimentos aberrantes. Trad. Laymert Garcia dos Santos. São Paulo: n-1, 2015.

Recebido: 23/7/2018

Aceito: 28/10/2019 
FERREIRA, F. 